\title{
Nursing interventions to reduce surgical site infection in potentially contaminated surgeries: an integrative review
}

\section{Intervenções de enfermagem para reduzir infecção do sítio cirúrgico em cirurgias potencialmente contaminadas: revisão integrativa}

\section{Intervenciones de enfermería para reducir infección del sitio quirúrgico en cirugía potencialmente contaminadas: revisión integrativa}

Tatiana Martins 1,* , Lúcia Nazareth Amante², Camila Vicente, Gabrielle Maciel de Sousa4, Emanuele Pozzebon Caurio ${ }^{4}$, Maria Elena Echevarría Guanilo ${ }^{1}$, Juliana Balbinot Reis Girondi

\section{ORCID IDS}

Martins T https://orcid.org/0000-0002-0954-5811

Amante LN https://orcid.org/0000-0002-5440-2094

Vicente C http://orcid.org/0000-0003-1918-0681

Sousa GM https://orcid.org/0000-0001-7620-1034

Caurio EP https://orcid.org/0000-0002-7365-1336

Guanilo MEE https://orcid.org/0000-0003-0505-9258

Girondi JBR https://orcid.org/0000-0002-3763-4176

\section{HOW TO CITE}

Martins T; Amante LN; Vicente C; Sousa GM; Caurio EP; Guanilo MEE; Girondi JBR. Intervenções de enfermagem para reduzir infecção do sítio cirúrgico em cirurgias potencialmente contaminadas: revisão integrativa. ESTIMA, Braz. J. Enterostomal Ther., 18, 2020: e1220. https://doi.org/10.30886/estima.v18.848_IN

\begin{abstract}
Objective: Identify nursing interventions that contribute to the reduction of surgical site infections in potentially contaminated surgeries. Methods: Integrative review, carried out in four databases. There were 5,888 articles published in the period from January 2008 to July 2018, in English, Portuguese and Spanish, from which nine articles were selected after final analysis. Results: The nursing interventions appeared according to the perioperative periods: preoperative (55.55\%), intraoperative (33.33\%), postoperative (66.66\%), being associated with: antibiotic therapy, trichotomy, alcoholic chlorhexidine bathing, hand hygiene, sterile glove/wear/ package change for fascia and skin closure, degermination, antisepsis, surgical classification, surgical time, care with dressings and drains, temperature and blood glucose control, patient education, discharge and post-hospital discharge orientation. Conclusions: Nursing interventions were identified in each perioperative period, proving to be essential for the qualification of nursing care and effective in reducing surgical site infection in potentially contaminated surgeries.
\end{abstract}

DESCRIPTORS: Nursing. Perioperative nursing. Patient safety. Enterostomal therapy.

\footnotetext{
1. Universidade Federal de Santa Catarina - Programa de Pós-Graduação em Enfermagem - Florianópolis (SC), Brazil.

2. Universidade Federal de Santa Catarina - Programa de Pós-Graduação em Gestão do Cuidado em Enfermagem - Modalidade Profissional - Florianópolis (SC), Brazil.

3. Universidade Federal de Santa Catarina - Residência Multiprofissional Integrada em Saúde - Florianópolis (SC), Brazil.

4. Universidade Federal de Santa Catarina - Graduação em Enfermagem - Florianópolis (SC), Brazil.

*Correspondence author: tatiana_martins15@hotmail.com

Received: Feb. 17, 2020 | Accepted: May 7, 2020
} 


\section{RESUMO}

Objetivo: Identificar as intervenções de enfermagem que contribuem para a redução das infecções de sítio cirúrgico (ISCS) em cirurgias potencialmente contaminadas. Métodos: Revisão integrativa, realizada em quatro bases de dados. Foram encontrados 5.888 artigos publicados no período de janeiro de 2008 a julho de 2018, nos idiomas inglês, português e espanhol, sendo selecionados nove artigos após análise final. Resultados: As intervenções de enfermagem apareceram conforme os períodos perioperatórios: pré-operatório (55,55\%), intraoperatório (33,33\%) e pós-operatório (66,66\%), estando associadas à: antibioticoterapia, tricotomia, banho de clorexidina alcoólica, higiene das mãos, troca de luva estéril/vestimenta/pacote para fechamento da fáscia e da pele, degermação, antissepsia, classificação cirúrgica, tempo cirúrgico, cuidados com curativos e drenos, controle de temperatura e glicemia, educação do paciente, orientações na alta e pós-alta hospitalar. Conclusões: As intervenções de enfermagem foram identificadas em cada período do perioperatório, mostrando-se essenciais para a qualificação da assistência de enfermagem e eficazes na redução da infecção do sítio cirúrgicos em cirurgias potencialmente contaminadas.

DESCRITORES: Estomaterapia. Enfermagem perioperatória. Segurança do paciente.

\section{RESUMEN}

Objetivo: Identificar las intervenciones de enfermería que contribuyan a la reducción de infecciones del sitio quirúrgico en cirugías potencialmente contaminadas. Métodos: Revisión integradora, realizada en cuatro bases de datos. Se encontraron 5.888 artículos publicados desde enero/2008 hasta julio/2018, en los idiomas inglés, portugués y español; y se seleccionaron nueve artículos después del análisis final. Resultados: Las intervenciones de enfermería aparecieron de acuerdo con los periodos perioperatorios: preoperatorio (55,55\%), intraoperatorio (33,33\%), postoperatorio (66,66\%), y se asociaron con: antibioticoterapia, tricotomía, baño con clorhexidina alcohólica, higiene de manos, cambio de guantes/ropa/paquete estériles para cerrar la fascia y la piel, degermación, antisepsia, clasificación quirúrgica, tiempo quirúrgico, cuidado con apósitos y drenajes, control de temperatura y glucosa em sangre, educación del paciente, pautas de alta y post alta. Conclusiones: Se identificaron intervenciones de enfermería em cada periodo perioperatorio, lo que demostró ser esencial para la calificación de la atención de enfermería y eficaz para reducir la infección del sitio quirúrgico en cirugías potencialmente contaminadas.

DESCRIPTORES: Enfermería. Enfermería perioperatoria. Seguridad del paciente. Estomaterapia.

\section{INTRODUCTION}

Surgical site infection (SSI) is one of the main complications after the surgical procedure ${ }^{1}$. The SSIs are defined as an infectious process that affects tissues, organs and cavities, and can be present in any type of surgical procedure ${ }^{2,3}$.

Although references indicate that the SSIs occur in any type of surgical procedure ${ }^{2,3}$, the occurrence is greater in surgeries classified as potentially contaminated 1. Potentially contaminated surgeries are those performed on tissues with the resident flora not numerous or where decontamination is a difficult process ${ }^{4}$.

In Brazil, the SSIs correspond to 14 to $16 \%$ of adverse events, occupying the third position among infections that occur in hospitalized patients ${ }^{3}$. In addition, they are responsible for increased morbidity, mortality and high hospital costs due to increased length of stay and health care costs ${ }^{1}$

In a survey conducted in 2018 by the National Association of Private Hospitals (ANAHP, Associação Nacional de Hospitais Privados), 7\% of hospitalized patients will acquire some infection during hospitalization. Reports that analyze health care around the world show the high global cost of poor care. It is noteworthy that errors associated with medication reach US\$ 42 billion per year, including unnecessary or inappropriate treatment, unsafe clinical practices and lack of training of health professionals ${ }^{5}$.

The SSIs consist of one of the events resulting from poor care, since they are characterized worldwide as one of the parameters of quality control of the service provided by a hospital ${ }^{2,3}$. Therefore, it is necessary the involvement of the team in the care of the patient in a surgical health condition in order to provide quality assistance throughout the perioperative period. For this, it is recommended that professionals identify possible preventive measures according to the peculiarities of each surgical procedure and the predisposing factors of each patient ${ }^{1}$.

The predisposing factors for SSI constitute a set of risk factors that can be intrinsic or extrinsic. The intrinsic factors consist of extremes of age, life habits, basic or associated pathologies; the extrinsic ones refer to the 
assistance procedures and surgical techniques adopted. The importance of the identification of these factors by the health team is given by the fact that most of the extrinsic factors can be avoided by actions of care, which are of entire responsibility of the care team that assists the patient ${ }^{1,6}$.

As a member of the health team, the nurse and the nursing team are also prominent in this situation, being considered essential for the care of the patient in a surgical health condition, since at this time patients need specific attention, care and guidance, due to the mixture of feelings such as fear, anxiety and doubts ${ }^{1,7}$.

Nursing is then responsible for receiving and assisting the patient during the perioperative period by systematizing nursing care, with implementation of the nursing process with which it is possible to establish nursing interventions ${ }^{7}$. The implementation of these nursing interventions with a focus on preventive measures, as well as their adequate implementation, has a significant impact on the reduction of SSI and its dissemination ${ }^{1}$.

Due to the significant burden in terms of morbidity and mortality together with the increased length of stay that SSIs cause, generating additional costs for health systems and service providers worldwide, knowledge of nursing interventions can positively interfere with health practices and is a relevant theme for this study ${ }^{8}$.

Given the context of SSI for professional practice, there was a need to seek the nursing interventions that contribute to the reduction of SSIs in potentially contaminated surgeries, in order to contribute to the dissemination and updating of information that is scientifically proven in recent studies.

\section{OBJECTIVE}

Identify the nursing interventions that contribute to the reduction of SSIs in potentially contaminated surgeries.

\section{METHODS}

Integrative review (IR) carried out from the elaboration of a protocol according to Whittemore and Knalf ${ }^{9}$, including: elaboration of the research question, objective, study design, inclusion and exclusion criteria, search strategies (advanced search), data collection, work collection, critical evaluation of the articles, information to be extracted from the productions, dissemination and schedule. This protocol was validated by two professors from the perioperative nursing area.

The IR research question was: What nursing interventions contribute to the reduction of SSIs in potentially contaminated surgeries? For the construction of the question, the PICO strategy was employed, where $\mathrm{P}$ represents the population, patient or problem (SSIs in potentially contaminated surgeries), I represents the intervention or area of interest (nursing interventions), $\mathrm{C}$ represents the control (reduction of SSIs in potentially contaminated surgeries) and $\mathrm{O}$ represents the outcome (reduction of SSI cases in potentially contaminated surgeries).

The second stage was the search of articles published in journals of the selected databases and scientific publishers: Latin American and Caribbean Literature in Health Sciences/Nursing Database (LILACS/ BDENF), US National Library of Medicine/Medical Literature Analysis and Retrieval System Online (PubMed/MEDLINE), Cumulative Index to Nursing \& Allied Health Literature (CINAHL) and SciVerse Scopus (Scopus).

This search required the selection of the Descriptors in Health Sciences (DeCS) and Medical Subject Headings (MeSH), in Portuguese, English and Spanish languages, being used: Nursing; Nursing Care; General Surgery; Patient Safety; Perioperative Nursing; Postoperative Nursing; Postoperative Period; Perioperative Care; Hospital Infection; Operative Wound Infection. From these, search strategies were developed by cross-referencing descriptors using Boolean resource logic in the search field " $A N D$ " or "OR", with the support of a librarian, as shown in Table 1.

The initial search of the articles in the databases occurred by only one of the researchers who exported the articles found in the databases to the Mendeley software ${ }^{10}$, in August 2018. At that moment, the automatic deletion of the duplicate articles in each database was performed, using the same software to freely manage the references ${ }^{10}$. Afterwards, the articles were preselected through the reading of the title and abstract, carried out in pairs and blindfolded, by all the authors of this study (doctor, master, nurse and nursing academics), during the months of August 2018 to February 2019. 
Table 1. Search strategies according to databases - Florianópolis, SC, Brazil.

\begin{tabular}{|c|c|}
\hline Database & Search strategy \\
\hline CINAHL & $\begin{array}{l}\text { ((Surgical Wound Infection* OR Surgical site infection*) OR ((infection*) AND (Perioperative OR Surgery OR } \\
\text { Surgical OR "pre operative" OR preoperative OR intraoperative OR "intra operative" OR postoperative OR } \\
\text { "post operative"))) AND (nursing) }\end{array}$ \\
\hline PubMed & $\begin{array}{l}\text { (("surgical wound infection"[MeSH Terms] OR ("surgical"[All Fields] AND "wound"[All Fields] AND } \\
\text { "infection"[All Fields]) OR "surgical wound infection"[All Fields] OR ("surgical"[All Fields] AND "wound"[All } \\
\text { Fields] AND "infections"[All Fields]) OR "surgical wound infections"[All Fields] OR ("surgical"[All Fields] } \\
\text { AND "site"[All Fields] AND "infection"[All Fields]) OR "surgical site infection"[All Fields] OR ("surgical"[All } \\
\text { Fields] AND "site"[All Fields] AND "infections"[All Fields]) OR "surgical site infections"[All Fields]) OR } \\
\text { (("infection"[MeSH Terms] OR "infection"[All Fields] OR "infections"[All Fields] OR "cross infection"[MeSH } \\
\text { Terms] OR ("cross"[All Fields] AND "infection"[All Fields]) OR "cross infection"[All Fields] OR "cross } \\
\text { infections"[All Fields]) AND (Perioperative[All Fields] OR "Perioperative Period"[Mesh Terms] OR } \\
\text { "surgery"[Subheading] OR "surgery"[Title/Abstract] OR "surgical procedures, operative"[MeSH Terms] } \\
\text { OR "surgical"[Title/Abstract] OR "operative surgical procedures"[All Fields] OR "general surgery"[MeSH } \\
\text { Terms] OR "Preoperative Period"[Mesh Terms] OR "pre operative"[All Fields] OR preoperative[All Fields] } \\
\text { OR "Intraoperative Period"[Mesh Terms] OR intraoperative[All Fields] OR "intra operative"[All Fields] OR } \\
\text { "postoperative period"[MeSH Terms] OR "postoperative"[All Fields] OR "post operative"[All Fields]))) AND } \\
\text { ("nursing"[Subheading] OR "nursing"[Title/Abstract] OR "nursing"[MeSH Terms] OR "nursing care"[MeSH } \\
\text { Terms] OR "perioperative nursing"[MeSH Terms] OR "postanesthesia nursing"[MeSH Terms]) AND } \\
\text { (English[lang] OR Portuguese[lang] OR Spanish[lang]) AND ("last 10 years"[PDat]) }\end{array}$ \\
\hline LILACS & 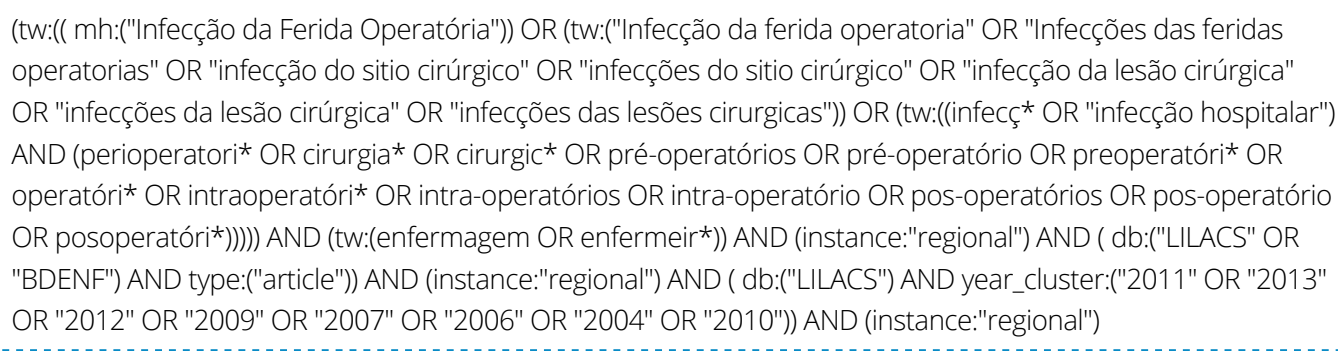 \\
\hline Scopus & $\begin{array}{l}\text { (Surgical Wound Infection OR Surgical site infection) OR (infection) AND (Perioperative OR Surgery OR } \\
\text { Surgical OR "pre operative" OR preoperative OR intraoperative OR "intra operative" OR postoperative OR } \\
\text { "post operative") AND Nursing }\end{array}$ \\
\hline
\end{tabular}

The selection of articles followed inclusion criteria such as: primary/original, qualitative and/or quantitative research published between January 1, 2008 and July 31, 2018, in English, Portuguese or Spanish; written by at least one nurse, focusing on SSIs in potentially contaminated surgeries. Reviews of literature, secondary studies/databases, experience and reflection reports, opinion articles, comments, theoretical essays, editorials, letters, reviews, dissertations, theses, monographs, abstracts in proceedings of events or journals, expanded abstracts, official documents of national and international programs, publications of duplicate works, materials aimed at pediatric patients, researches conducted with animals, cadavers, in vitro, articles not available for full visualization and/or unrelated to the subject were excluded.

The articles selected in the preselection were compared and discussed in a consensus meeting, composed by all members of the research. After this selection, the articles went through a new duplicate check, this time, among the databases, manually by the researchers themselves, reaching a sample of articles selected for full reading.

The full reading was conducted from February to March 2019, by all authors simultaneously, and at the end the results were compared and discussed again in a consensus meeting with all members.

The data of the selected articles from the full reading and with the application of the Revised Standards for Quality Improvement Reporting Excellence (SQUIRE 2.0) were organized in a frame built in Microsoft Word software, detaching: reference, objective, method and results; consisting of the third stage of this IR.

In the fourth stage, similar information was sorted, coded, categorized, summarized, compared and grouped. In the fifth and last stage, the presentation and synthesis of 
knowledge in the form of charts were elaborated, allowing the reader to verify the conclusions of the IR, contributing to a new understanding of the phenomenon.

This study was not submitted to a committee on ethics in research with human beings because it used sources in the public domain to conduct it, but followed the ethics in research with human beings in the search, analysis, discussion and presentation of results.

\section{RESULTS}

Initially, 5,888 articles were selected, 2,092 of which were excluded due to duplicity or impossibility of complete visualization, reaching a total of 3,796 articles for preselection, of which 28 were read in full and evaluated by the application of SQUIRE 2.0, resulting in 9 articles in the final result. The sequence of this identification, selection and inclusion of the articles is presented in Fig. 1, according to the article selection flow chart Preferred Reporting Items for Systematic Reviews and Meta-Analyses (PRISMA).

The majority of the articles were published in the English language accounting for seven (77.77\%) ${ }^{11-17}$ articles, with three (33.33\%) $)^{13,15,16}$ published by professionals from the United States of America (USA). The publication period prevailed from 2013 to 2014 , with four $(44.44 \%)^{12-}$ ${ }^{14,18}$ published articles. The syntheses and summarization are explained in Table 2.

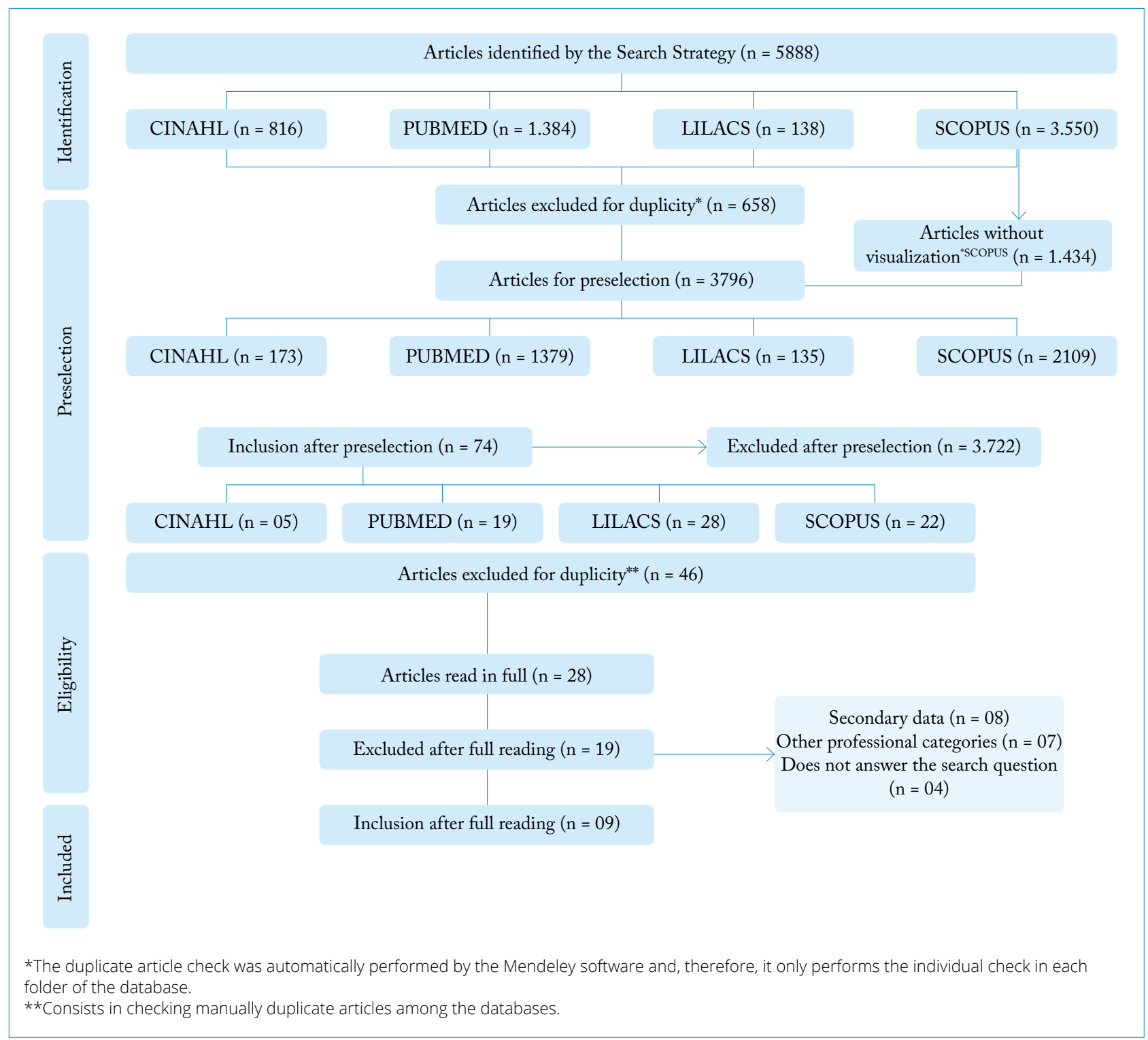

Figure 1. Identification, selection and inclusion flowchart of the articles, according to Prisma - Florianópolis, SC, Brazil. 
Table 2. Articles description, scientific evidence and degree of recommendation - Florianópolis, SC, Brazil.

\begin{tabular}{|c|c|c|c|c|c|c|}
\hline N. & $\begin{array}{l}\text { Year; } \\
\text { Country; } \\
\text { Language }\end{array}$ & Title & Type & Size & Objective & $\begin{array}{c}\text { Evidence and } \\
\text { Recommendation }\end{array}$ \\
\hline 1 & $\begin{array}{l}2017 \\
\text { Ireland } \\
\text { English }\end{array}$ & $\begin{array}{l}\text { Effectiveness of individually } \\
\text { packed sterile gauze versus } \\
\text { drum packed gauze on the } \\
\text { incidence of surgical site } \\
\text { infection (SSI) in surgical } \\
\text { ward AlIMS, New Delhi'7 }\end{array}$ & $\begin{array}{l}\text { Descriptive } \\
\text { cross- } \\
\text { sectional } \\
\text { study }\end{array}$ & $\begin{array}{c}40 \\
\text { patients }\end{array}$ & $\begin{array}{l}\text { Determine the relationship } \\
\text { between the individually- } \\
\text { wrapped sterile gauze } \\
\text { and the package of sterile } \\
\text { gauze with the incidence } \\
\text { of SSI. }\end{array}$ & $2 C-B$ \\
\hline 2 & $\begin{array}{c}2017 \\
\text { USA } \\
\text { English }\end{array}$ & $\begin{array}{l}\text { A semi-automated } \\
\text { assessment of sarcopenia } \\
\text { using psoas area } \\
\text { and density predicts } \\
\text { outcomes after } \\
\text { pancreaticoduodenectomy } \\
\text { for pancreatic } \\
\text { malignancy }{ }^{16}\end{array}$ & $\begin{array}{c}\text { Prospective } \\
\text { cohort }\end{array}$ & $\begin{array}{c}116 \\
\text { patients }\end{array}$ & $\begin{array}{l}\text { To demonstrate through } \\
\text { semiautomated and } \\
\text { manual techniques } \\
\text { the relationship } \\
\text { between postsurgical } \\
\text { sarcopenia and probable } \\
\text { adverse events in } \\
\text { patients undergoing } \\
\text { pancreatoduodenectomy. }\end{array}$ & $2 C-B$ \\
\hline 3 & $\begin{array}{c}2016 \\
\text { USA } \\
\text { English }\end{array}$ & $\begin{array}{l}\text { Using bundled } \\
\text { interventions to reduce } \\
\text { surgical site infection after } \\
\text { major gynecologic cancer } \\
\text { surgery }\end{array}$ & $\begin{array}{l}\text { Intervention } \\
\text { study }\end{array}$ & 625 cases & $\begin{array}{l}\text { Diagnose whether } \\
\text { implementing an evidence- } \\
\text { based standard of } \\
\text { perioperative care can } \\
\text { reduce SSI rates. }\end{array}$ & $2 C-B$ \\
\hline 4 & $\begin{array}{c}2014 \\
\text { China } \\
\text { English }\end{array}$ & $\begin{array}{l}\text { Application of a } \\
\text { glycaemic control } \\
\text { optimization programme } \\
\text { in patients with stress } \\
\text { hyperglycaemia }{ }^{14}\end{array}$ & $\begin{array}{l}\text { Controlled } \\
\text { and } \\
\text { randomized } \\
\text { clinical trial }\end{array}$ & $\begin{array}{c}86 \\
\text { patients }\end{array}$ & $\begin{array}{l}\text { Investigate the clinical } \\
\text { events of a program } \\
\text { for glycemic control in } \\
\text { patients with postsurgical } \\
\text { stress hyperglycemia in } \\
\text { hepatobiliary or pancreatic } \\
\text { surgeries. }\end{array}$ & $2 B-B$ \\
\hline 5 & $\begin{array}{c}2014 \\
\text { Brazil } \\
\text { Portuguese }\end{array}$ & $\begin{array}{l}\text { Vigilância pós-alta em } \\
\text { cirurgia geral: assistência } \\
\text { de enfermagem } \\
\text { sistematizada como } \\
\text { ferramenta no controle de } \\
\text { infecções }^{18} \text {. }\end{array}$ & $\begin{array}{l}\text { Descriptive } \\
\text { cross- } \\
\text { sectional } \\
\text { study }\end{array}$ & $\begin{array}{c}96 \\
\text { patients }\end{array}$ & $\begin{array}{l}\text { Describe and analyze the } \\
\text { behavior of SSI in patients } \\
\text { undergoing general surgery } \\
\text { and propose a protocol for } \\
\text { perioperative nursing care. }\end{array}$ & $2 C-B$ \\
\hline 6 & $\begin{array}{c}2013 \\
\text { USA } \\
\text { English }\end{array}$ & $\begin{array}{l}\text { Effectiveness of } 2 \% \text { CHG } \\
\text { cloth bathing for reducing } \\
\text { surgical site infections }{ }^{13} \text {. }\end{array}$ & $\begin{array}{c}\text { Prospective } \\
\text { cohort }\end{array}$ & $\begin{array}{c}335 \\
\text { patients }\end{array}$ & $\begin{array}{l}\text { Analyze the efficacy } \\
\text { of bathing with } 2 \% \\
\text { chlorohexidine gluconate } \\
\text { cloths in the preoperative } \\
\text { period as a way to reduce } \\
\text { SSI in patients undergoing } \\
\text { general, vascular or } \\
\text { orthopedic surgery. }\end{array}$ & $2 B-B$ \\
\hline 7 & $\begin{array}{l}2013 \\
\text { England } \\
\text { English }\end{array}$ & $\begin{array}{l}\text { Performance and ease of } \\
\text { use evaluation of a new } \\
\text { surgical post-operative } \\
\text { foam island dressing in } \\
14 \text { patients undergoing } \\
\text { elective gynaecological } \\
\text { surgery } 12\end{array}$ & $\begin{array}{l}\text { Clinical } \\
\text { outcome }\end{array}$ & $\begin{array}{c}14 \\
\text { patients }\end{array}$ & $\begin{array}{l}\text { To evaluate the ease of } \\
\text { use and effectiveness of a } \\
\text { new foam dressing used } \\
\text { after surgery in women } \\
\text { undergoing elective } \\
\text { gynecological surgery. }\end{array}$ & $2 C-B$ \\
\hline
\end{tabular}


Table 2. Continuation...

\begin{tabular}{|c|c|c|c|c|c|c|}
\hline N. & $\begin{array}{c}\text { Year; } \\
\text { Country; } \\
\text { Language }\end{array}$ & Title & Type & Size & Objective & $\begin{array}{c}\text { Evidence and } \\
\text { Recommendation }\end{array}$ \\
\hline 8 & $\begin{array}{c}2012 \\
\text { Brazil } \\
\text { Portuguese }\end{array}$ & $\begin{array}{l}\text { Fatores associados a } \\
\text { infecção de sítio cirúrgico em } \\
\text { um hospital na Amazônia } \\
\text { ocidental brasileira }^{19}\end{array}$ & $\begin{array}{l}\text { Prospective } \\
\text { cross- } \\
\text { sectional } \\
\text { study }\end{array}$ & $\begin{array}{c}2203 \\
\text { patients }\end{array}$ & $\begin{array}{l}\text { Identify the factors } \\
\text { associated to SSI according } \\
\text { to the data of the patients } \\
\text { and the anesthetic- } \\
\text { surgical procedures in the } \\
\text { perioperative period. }\end{array}$ & $2 C-B$ \\
\hline 9 & $\begin{array}{c}2009 \\
\text { Turkey } \\
\text { English }\end{array}$ & $\begin{array}{l}\text { The effect of nurse- } \\
\text { performed preoperative skin } \\
\text { preparation on postoperative } \\
\text { surgical site infections in } \\
\text { abdominal surgery }{ }^{11}\end{array}$ & Experimental & $\begin{array}{c}82 \\
\text { patients }\end{array}$ & $\begin{array}{l}\text { Analyze the effect } \\
\text { of preoperative skin } \\
\text { preparation procedures } \\
\text { performed by nurses in } \\
\text { SSI related to abdominal } \\
\text { surgeries. }\end{array}$ & $3 B-B$ \\
\hline
\end{tabular}

The articles report results of research performed with people in operative period for surgeries of the gynecological system $^{12,15}$, digestive system ${ }^{14,16,19}$ and general surgery ${ }^{11,13,18,19}$; one of the articles was the report of a research on the technique of sterilization of the gauzes and the occurrence of SSI17. The results of the selected articles are presented in Table 3.

Table 3. Description of the articles according to the results of the articles - Florianópolis, SC, Brazil.

\begin{tabular}{|c|c|}
\hline N. & Result \\
\hline 1 & $\begin{array}{l}\text { A reduction in the incidence of SSI is evident with the use of the individually-wrapped sterile gauze package compared to the } \\
\text { use of cylinder-packed gauze. The individual sterilization form allows the aseptic technique to be maintained. Recommended } \\
\text { aseptic technique during the change of dressings in the postoperative } 24 \text { to } 48 \text { hours }{ }^{17} \text {. }\end{array}$ \\
\hline 2 & $\begin{array}{l}\text { The combination of semiautomated technique and manual preoperative clinical evaluation can improve the prediction of } \\
\text { results in patients with pancreatic malignancy. The lowest values of the total psoas area index }(\mathrm{TPAI})(\mathrm{OR}=0.34 ; \mathrm{p}=0.009) \\
\text { and Hounsfield mean units }(\mathrm{HU})(\mathrm{OR}=0.84 \mathrm{p}=0.002) \text { were predictive of discharge from the specialized ward, as well as was } \\
\text { protective against the risk of organ/surgical space-type SSI, both in the univariate }(\mathrm{OR}=3.12 ; \mathrm{p}=0.019) \text { and multivariate (OR } \\
=4.23 ; \mathrm{p}=0.014)^{16} \text {. }\end{array}$ \\
\hline 3 & $\begin{array}{l}\text { The implementation of a bundle of perioperative care interventions reduces the occurrence and risk of SSI by } 82.4 \% \text {, } \\
\text { obtaining } 6 \% \text { infection before intervention and } 1.1 \% \text { infection after intervention. The bundle includes: patient/family } \\
\text { education; pre- and postoperative chlorhexidine bath and dressing; prophylactic antibiotic and redosing during the } \\
\text { procedure; change of sterile glove before closure of the fascia by the entire surgical team, clothing and package for } \\
\text { closure of the fascia and skin; care with normothermia and glycemic control; trichotomy only when necessary; good } \\
\text { hand hygiene practices; dressing change in } 24 \text { to } 48 \text { hours; post-hospital discharge follow-up and chlorhexidine } \\
\text { dispensation for home }{ }^{15} \text {. }\end{array}$ \\
\hline 4 & $\begin{array}{l}\text { Participants undergoing the Glycemic Control Optimization Program (GCOP) reached blood glucose levels faster than those } \\
\text { of the conventional intensive insulin therapy group (CIIT), as well as abdominal infection rates (GCOP: } 1 ; \text { CIIT: 7) and SSI } \\
\text { (GCOP: 2; CIIT: 7) were lower in those undergoing GCOP than in those undergoing CIIT }{ }^{14} \text {. }\end{array}$ \\
\hline 5 & $\begin{array}{l}\text { The SSI occurred in } 6.3 \% \text { of the cases, with a predominance of superficial infections (83.3\%). Of the infections, } 76.5 \% \text { did not } \\
\text { obtain nursing guidance mainly related to the care of the surgical wound (89.7\%). The failure in the nursing guidelines for the } \\
\text { prevention of SSI was highlighted, evidencing the need for a method of post-hospital discharge surveillance that allows the } \\
\text { identification and notification of cases, reducing the underreporting of cases }{ }^{18} \text {. }\end{array}$ \\
\hline 6 & $\begin{array}{l}\text { Preoperative bathing with } 2 \% \text { gluconate chlorhexidine cloths generates an overall reduction of infection from } 6.3 \text { to } 2.1 \% \text {, } \\
\text { including space and organ infections }{ }^{13} \text {. }\end{array}$ \\
\hline
\end{tabular}


Table 3. Continuation...

\begin{tabular}{|c|c|}
\hline N. & Result \\
\hline 7 & $\begin{array}{l}\text { The foam dressing with transparent film brings benefits and reduces the risks of SSI, having } 0 \% \text { of infection in the study } \\
\text { carried out, because it allows the protection of the skin together the visualization and evaluation of the perilesional skin by } \\
\text { the nurse, allowing its permanence for } 48 \mathrm{~h} \text { in the postoperative, even after the bath }{ }^{12} \text {. }\end{array}$ \\
\hline 8 & $\begin{array}{l}\text { Nursing care focused on risk factors may have repercussions on the reduction of the occurrence of SSI, these cares } \\
\text { refer to: degermination and antisepsis, trichotomy with razor blade, type of surgery with emphasis on those classified } \\
\text { as potentially contaminated surgeries, surgical risk ASA II, surgical time, use of antibiotic therapy and care with drains } \\
\text { and dressings }{ }^{19} \text {. }\end{array}$ \\
\hline 9 & $\begin{array}{l}\text { In the group in which the chlorhexidine bath was not applied, the risk of infection was } 4.76 \text { times higher, even after } \\
\text { age and sex corrections, showing the importance of preparing the skin by bathing with degermating chlorhexidine } \\
\text { before surgery }{ }^{11} \text {. }\end{array}$ \\
\hline
\end{tabular}

Nursing interventions and preoperative phase guidelines were evidenced in five $(55.55 \%)^{11,13,15,18,19}$ articles, highlighting hand hygiene in one $(20 \%)^{15}$ article; trichotomy without razor, only when necessary in three $(60 \%)^{11,15,19}$; bath with alcoholic chlorhexidine in four $(80 \%)^{11,13,15,18}$ and the administration of prophylactic antibiotic therapy in patients by the nursing team in three $(60 \%)^{15,18,19}$. Intraoperative care was addressed in three (33.33\%) articles ${ }^{15,18,19}$, whatever they are: the exchange of sterile gloves; the surgical clothing and sterile packages by the entire surgical team (including nursing staff) before the closure of the fascia and $\operatorname{skin}^{15}$; degermination and antisepsis of the hands ${ }^{15,19}$; classification of the type of procedure $^{18,19}$; time of surgery ${ }^{15}$ and antibiotic redosing ${ }^{15}$.

It should be noted that an article presented the result on the sterilization process ${ }^{17}$, comparing the use of sterilized gases in cylinders and in individual packs and the occurrence of SSI, verifying that there was a constant decline in the occurrence of SSI with the use of sterilized gases in individual packs.

The nursing interventions related to the postoperative period appeared in six (66.66\%) articles ${ }^{12,14,15,17-19}$. One article $(11.11 \%)^{15}$ approached bath care with alcoholic chlorhexidine and hand hygiene. Nursing interventions for the wound and drains were discussed in four (44.44\%) articles ${ }^{13,15,17,19}$, highlighting the benefits of covering foam with transparent film in two $(25 \%)^{13}$, chlorhexidine dressing in one $(25 \%)^{15}$, change period of these dressing between 24 and 48 hours in two $(50 \%)^{13,17}$, sterile technique for dressing change in two $(50 \%)^{17,19}$ and drain care in one (25\%)19. The monitoring of vital signs was observed in two $(22.22 \%)$ articles ${ }^{14,15}$, being considered an important care for the reduction of SSI, covering the control of the temperature in one $(50 \%)^{15}$ and of the glycemia by means of the hemoglucotest in both articles $(100 \%)^{14,15}$.

In the case of the health education process and nursing guidance on the prevention of SSI either preoperatively, postoperatively or at hospital discharge were evidenced in two articles $(22.22 \%)^{15,18}$, as well as home follow-up to patients and family members ${ }^{15,18}$. Of these, surveillance after hospital discharge to minimize underreporting rates was addressed in one (50\%) article ${ }^{18}$.

\section{DISCUSSION}

The SSI is one of the most common health-related infections in the hospital environment, and is also the most frequent complication in surgical patients. Despite the advance in technologies, methods and resources for health care, this reality still persists in hospitals in Brazil1. This type of infection is still a concern of health professionals due to its consequences in the economic sector, both for the institution and for biopsychosocial issues, as well as the fact that its occurrence is directly related to the behavior of professionals during their health actions ${ }^{20,21}$,in addition to noncompliance with recommended actions, since they are infections that can be avoided1.

The evaluation of the health professional is essential for the perception of factors that can trigger and prevent SSI, because the knowledge of risk factors serves as a measure to reduce its occurrence ${ }^{1,22}$. Taking into account that the nursing team is the profession that spends the longest period in direct care with the patient and has 
technical-scientific competence to perform the perioperative care, besides assuming a primordial role in the control of hospital infections ${ }^{23}$.

The nursing interventions found in the IR data search for the preoperative period are: bath and skin preparation ${ }^{11,13,15,18}$, trichotomy ${ }^{11,19}$, antibioticoprophylaxis ${ }^{15,18,19}$ and surgical hand antisepsis ${ }^{15}$, use of sterile gauzes in individual packs ${ }^{17}$. These highlighted nursing interventions are in accordance with the recommended by the Brazilian national and international health regulation and control agency ${ }^{3}$, as well as with the Healthcare related infection prevention measures established by the Ministry of $\mathrm{Health}^{24}$, the recommendations of the Brazilian Society of Surgical Center Nursing (SOBECC, Sociedade Brasileira de Enfermagem de Centro Cirúrgico) ${ }^{21}$, national ${ }^{1,25}$ and international articles ${ }^{26,27}$.

The articles found in this research ${ }^{11,13,15,18}$ highlighted the importance of chlorhexidine bath in patients with potentially contaminated surgeries for the prevention of SSI. It is recommended that the bath should be performed with soap and water, the night before or the morning of surgery ${ }^{3,28}$; there is no consensus on the indication of the use of antiseptic for all surgeries, however, its use is indicated in large surgeries, with implants or in cases of outbreaks of infection in surgeries. Trichotomy should be performed only when necessary, immediately before the surgical procedure, without the use of blades, prioritizing the use of electric tricotomizers, trimmers or scissors ${ }^{11,19}$, being in accordance with the Healthcare related infection prevention measures established by the Brazilian Ministry of Health ${ }^{24}$. This document evidences other preoperative nursing interventions not reported in the articles of this IR, such as: hospitalization preferably on the day of the surgical procedure or in less than 24 hours, identification of preexisting infections (urinary tract infection, skin and soft tissue infection, dental infection) and antimicrobial prophylaxis through the administration of the antibiotic up to one hour before the surgical incision with duration less than or equal to 24 hours $^{24}$.

The prevalence of prophylactic antibiotic therapy added to the risk factors under its use and inadequate indication contribute significantly to the development of $\mathrm{SSI}^{15,18,19}$. Among the findings, a high rate of antibiotic prophylaxis in potentially contaminated elective surgeries was observed, as well as a high prevalence of inadequate prescriptions. These findings suggest areas for intervention and implementation of antibiotic management policies in hospital institutions ${ }^{27}$.

Intraoperative nursing interventions are associated with surgical environment ${ }^{15,18,19}$, surgical antisepsis of the hands with degermating antiseptic or alcohol-based product ${ }^{15,19}$, potential for contamination of operative wound ${ }^{18,19}$, surgical duration ${ }^{19}$ and sterile glove replacement ${ }^{15}$. These interventions were also recommended in national ${ }^{1,8}$ and international original articles ${ }^{28}$, national ${ }^{29}$ and international systematic reviews $^{30}$, and in the recommendations established by the Centers for Disease Control and Prevention (CDC) ${ }^{31}$.

Regarding the potential for contamination of surgery, Brazilian articles ${ }^{16,18,19}$ demonstrated the predominance of the occurrence of SSI in surgeries classified as potentially contaminated. The authors of these articles identified that patients submitted to duodenopancreatectomy intervention presented fragility associated with adverse events due to reduced capacity to recover from physiological injury, such as sarcopenia, significant loss of muscle strength and volume. For this, it was found that the sarcopenia imaging evaluations were independent predictors of the outcomes by adjusting to the various risk factors, being an important tool to enable risk stratification of patients undergoing duodenopancreatectomy and possible chances of SSI in the abdominal region ${ }^{16}$.

Regarding the antibiotic prophylaxis in the intraoperative period, an article found in this IR highlighted the importance of antibiotic redosing in the intraoperative period 15 , however the Brazilian national and international health regulatory and control agency ${ }^{27}$ presents as recommendations not favorable for patient safety the routine use of vancomycin as a prophylactic drug associated with the postponement of surgery to provide parenteral nutrition. Still in this period, some nursing interventions were not mentioned in the articles of this IR, including the preparation of the skin of the patient with degermination, followed by antisepsis with alcohol-based solution; location of the chest drain mainly outside the surgical incision and in closed systems; inspection of the surgical box; surgical clothing; glycemic control; maintenance of normothermia; optimization of tissue oxygenation and use of plastic protectors in wounds in gastrointestinal and biliary tract surgeries ${ }^{24}$.

The glycemic control ${ }^{14,15}$ is recommended during the first six hours immediately after the postoperative period, in order to keep the glycemic value below or equal to $200 \mathrm{mg} / \mathrm{dl}$, stressing that there should be glycemic control 
in the preoperative and postoperative periods, keeping the values below $180 \mathrm{mg} / \mathrm{dl}$ and glycemic hemoglobin below $7 \%$ throughout the perioperative period ${ }^{24}$. The temperature during the entire intraoperative period, regardless of the type of surgery, must be maintained at or above $35.5^{\circ} \mathrm{C}$, because hypothermia $\left(\mathrm{T}<35^{\circ} \mathrm{C}\right)$ is a risk factor for increased infections, postoperative bleeding and cardiac events ${ }^{15,24}$.

Postoperative care ${ }^{12,15,17}$ includes strict care of the surgical wound and drains. One of the articles emphasizes the effectiveness of the use of antiseptic dressings ${ }^{15}$, and the Brazilian national health regulatory and control agency ${ }^{24}$ preconizes as not recommended approaches the routine use of sutures and dressings impregnated with antiseptics.

In addition to these findings, it was possible to identify that the communication and guidance given to the patient and family about perioperative care at hospital discharge contribute to reducing the development of $\mathrm{SSI}^{15,18}$, because they generate empowerment, tranquility and stimulus for self-care effectively. A communication strategy found in this IR study ${ }^{18}$ is also recommended by the Brazilian national and international health regulation and control agency ${ }^{3}$, by bringing that the use of guidelines in a systematized format through the planning of care or preestablished protocols ensure the continuation of behaviors and better understanding of the patient's needs, contributing to effective care, both in the hospital and at home, after discharge.

Notification and follow-up during hospitalization and after discharge, as well as surveillance performed in a standardized manner, show significant results in the control and reduction of infection rates ${ }^{23,24}$. For some authors, this milestone demonstrates an underreporting that occurs mainly after discharge from hospital, and it is suggested to seek these cases even at home. For this, one of the best ways to perform monitoring is through the implementation of outpatient monitoring, allowing the accuracy of information, implementing nursing care and monitoring cases, generating impact on clinical practice and thus reducing the risk of underreporting and hospital infections, specifically the SSIs ${ }^{22,24,32}$.

It is expected that this research will contribute as a source of knowledge dissemination for health professionals, as well as in the applicability of clinical practice in nursing, with the objective of bringing improvements to the quality of care, avoiding the complications resulting from the preventive risk factors for SSI and, consequently, reducing the rates of this type of occurrence, institutional expenditure, length of stay and the severity of cases. It is worth highlighting the importance of up-to-date scientific knowledge for an adequate clinical evaluation, identification of risk factors, the hospital follow-up up to the outpatient, after discharge and supervision of the entire nursing team and the surgical setting.

The study is limited to having been conducted in only four databases, included only one type of surgical classification and covered only articles that had the presence of nurses. Broader studies are suggested, including interventions by the multiprofessional team in perioperative care.

\section{CONCLUSION}

It was identified that nursing interventions contribute to reduce the occurrence of surgical site infection in potentially contaminated surgeries, including preoperative (prophylactic antibiotic therapy, trichotomy, alcoholic chlorhexidine bath and hand hygiene), intraoperative (sterile glove replacement, clothing and package for closure of the fascia and skin), degermination and antisepsis, surgical classification as potentially contaminated, surgical time and antibiotic reduction) and postoperative (bath with alcoholic chlorhexidine, hand hygiene, care with dressings and drains, temperature and glycemia control, use of sterile gauzes in individual packs, patient education, guidance on discharge and postdischarge).

The conclusion is that nursing interventions are essential for the qualification of nursing care to the patient in the perioperative period, revealing the knowledge and commitment with the care provided to reduce the occurrence of surgical site infections in potentially contaminated surgeries.

\section{AUTHOR'S CONTRIBUTION}

\section{Conceptualization, Martins $\mathrm{T}$ and Amante LN;} Methodology, Martins T and Amante LN; Data and results analysis, Girondi JBRe Guanilo MEE; Discussion development Girondi JBR; Investigation, Martins T, Vicente C, Sousa GM and Caurio EP; Writing - Original Draft, Martins T, Vicente C, Sousa GM and Caurio EP; Writing - Review and Editing, Martins T, Amante LN, Vicente C, Sousa GM and Caurio EP; Supervision, Martins T e Amante LN. 


\section{REFERENCES}

1. Santana CA, Oliveira CGE. Assistência de enfermagem na prevenção de infecções de sítio cirúrgico: uma revisão integrativa da literatura. Rev Eletrôn Atualiza Saúde. 2015;1(1):76-88.

2. [WHO] World Health Organization. Global guidelines on the prevention of surgical site infection. Geneva: WHO; 2016. [cited on 4 Abr 2019]. Available at: https://apps.who.int/ iris/bitstream/handle/10665/250680/9789241549882-eng. pdf?sequence $=8$

3. Brasil. Agência Nacional de Vigilância Sanitária (Anvisa). Sítio Cirúrgico - Critérios Nacionais de Infecções relacionadas à assistência à saúde: Gerência Geral de Tecnologia em Serviços de Saúde, Gerência de Investigação e Prevenção das Infecções e dos Eventos Adversos. Brasília: Anvisa; 2009. [cited on 20 Out 2019]. Available at: http://www.anvisa.gov. br/servicosaude/manuais/criterios_nacionais_ISC.pdf

4. Medeiros AC, Carvalho MDF. Infecção em cirurgia. J Surg Cl Res. 2016;7(2):60-73. https://doi.org/10.20398/jscr.v7i2.11413

5. [ANAHP]. Associação Nacional de Hospitais Privados. Observatório Anahp 2018 [Internet]. São Paulo: Apahp. [cited on $4 \mathrm{Abr}$ 2019]. Available at: https://www.anahp. com.br/noticias/observatorio-anahp-2018-e-lancado-nahospitalar/

6. Sinésio MCT, Magro MCS, Carneiro TA, Silva KGN. Fatores de risco às infecções relacionadas à assistência em unidades de terapia intensiva. Cogitare Enferm. 2018;23(2):e53826. https://doi.org/10.5380/ce.v23i2.53826

7. Almeida MC. Enfermagem perioperatória e sua inserção nos cursos de graduação [Dissertação]. [Manaus]: Universidade Federal do Amazonas - Universidade Federal do Pará; 2015.

8. Carvalho RLR, Campos CC, Franco LMC, Rocha AM, Ercole FF. Incidence and risk factors for surgical site infection in general surgeries. Rev Latino-Am Enfermagem. 2017;25:e2848. https://doi.org/10.1590/1518-8345.1502.2848

9. Whittemore R, Knafl K. The integrative review: updated methodology. J Adv Nurs. 2005;52(5):546-53. https://doi. $\operatorname{org} / 10.1111 / \mathrm{j} .1365-2648.2005 .03621 . x$

10. Mendeley. Mendeley - Reference management software \& researcher network [Internet]. Amsterdam: Elservier; 2019. [cited on 20 Abr 2020]. Available at: https://www.mendeley. com/?interaction_required=true.

11. Dizer B, Hatipoglu S, Kaymakcioglu N, Tufan T, Yava A, Iyigun $E$, et al. The effect of nurselperformed preoperative skin preparation on postoperative surgical site infections in abdominal surgery. J Clin Nurs. 2009;18(23):3325-32. https://doi.org/10.1111/j.1365-2702.2009.02885.x

12. Gibson E, Stephens C. Performance and ease of use evaluation of a new surgical post-operative foam island dressing in 14 patients undergoing elective gynaecological surgery. J Tissue Viability. 2013;22(2):37-41. https://doi. org/10.1016/j.jtv.2013.02.001
13. Graling PR, Vasaly FW. Effectiveness of 2 CHG cloth bathing for reducing surgical site infections. AORN J. 2013;97(5):54751. https://doi.org/10.1016/j.aorn.2013.02.009

14. Shi Z, Tang S, Chen Y, Lee DT-F, Chair SY, Jiang B, et al. Application of a glycaemic control optimization programme in patients with stress hyperglycaemia. Nurs Crit Care. 2014;21(5):304-10. https://doi.org/10.1111/nicc.12121

15. Johnson MP, Kim SJ, Langstraat $C L$, Jain $S$, Habermann EB, Wentink JE, et al. Using bundled interventions to reduce surgical site infection after major gynecologic cancer surgery. Obstet Gynecol. 2016;127(6):1135-44. https://doi. org/10.1097/AOG.0000000000001449

16. Namm JP, Thakrar KH, Wang C-H, Stocker SJ, Sur MD, Berlin J, et al. A semi-automated assessment of sarcopenia using psoas area and density predicts outcomes after pancreaticoduodenectomy for pancreatic malignancy. J Gastrointest Oncol. 2017;8(6):936-44. https://doi. org/10.21037/jgo.2017.08.09

17. Nemkholam C, Anurag S. Effectiveness of individually packed sterile guaze versus drum packed gauze on the incidence of surgical site infection (SSI) in Surgical Ward AllMS, New Delhi. Int J Nurs Educ. 2017;9(3):55-7. https://doi. org/10.5958/0974-9357.2017.00071.X

18. Xavier AT, Silva PCV. Vigilância pós-alta em cirurgia geral: assistência de enfermagem sistematizada como ferramenta no controle de infecções. Rev Enferm UFPE On Line. 2014;8(3):606-15.

19. Aguiar APL, Prado PR, Opitz SP, Vasconcelos SP, Faro ARMC. Fatores associados à infecção de sítio cirúrgico em um hospital na Amazônia Ocidental brasileira. Rev SOBECC. 2012;17(3):60-70.

20. RochaJPJ, Lages CAS. O Enfermeiro e a prevenção das infecções do sítio cirúrgico. Cadernos UniFOA. 2016;30:117-28.

21. [SOBECC] Associação Brasileira de Enfermeiros de Centro Cirúrgico, Recuperação Anestésica e Centro de Material e Esterilização. Prevenção e controle de infecção do sítio cirúrgico. São Paulo: Manole. 2013;4:157-72.

22. Oliveira AC, Carrara D, Araújo MPS. Infecção do sítio cirúrgico. In: Oliveira AC, Silva MVG. Teoria e prática na prevenção da infecção do sítio cirúrgico. Barueri: Manole; 2015.

23. Souza ISB, Santana AC, D'Alfonso Júnior G. A ocorrência de infecção do sítio cirúrgico: um estudo de revisão. Rev Med Minas Gerais. 2018;28(Suppl 5):e-S280521.

24. Brasil. Agência Nacional de Vigilância Sanitária (Anvisa). Medidas de prevenção de infecção relacionada à assistência à saúde. Brasília: Anvisa; 2017. [cited on 04 Abr 2019]. Available at: http://portal.anvisa.gov.br/ documents/33852/3507912/Caderno+4+-+Medidas+de+Pr even\%C3\%A7\%C3\%A30+de+Infec\%C3\%A7\%C3\%A3o+Relac ionada+\%C3\%A0+Assist\%C3\%AAncia+\%C3\%A0+Sa\%C3\%B Ade/a3f23dfb-2c54-4e64-881c-fccf9220c373 
25. Freitas PS, Romanzini AE, Ribeiro JC, Bellusse GC, Galvão CM. Controle glicêmico no perioperatório: evidências para a prevenção de infecção de sítio cirúrgico. Rev Eletr Enf. 2013;15(2):541-50. https://doi.org/10.5216/ree.v15i2.23898

26. Giske A, Nymo LS, Fuskevåg O-M, Amundsen S, Simonsen GS, Lassen K. Systemic antibiotic prophylaxis prior to gastrointestinal surgery - is oral administration of doxycycline and metronidazole adequate? Rev Infect Dis. 2017;19(11-12):785-91. https://doi.org/10.1080/23744235. 2017.1342044

27. Ou $Y$, Jing B-Q, Guo F-F, Zhao $L$, Xie $Q$, Fang $Y-L$, et al. Audits of the quality of perioperative antibiotic prophylaxis in Shandong province, China, 2006 to 2011. Am J Infect Control. 2016;42(5):516-20. https://doi.org/10.1016/j. ajic.2014.01.001

28. Vinchurkar K, Pattanshetti VM, Togale M, Hazare S, Gokak V. Outcome of pancreaticoduodenectomy at low-volume centre in Tier-II city of India. Indian J Surg Oncol. 2018;9(2):220-4. https://doi.org/10.1007/s13193-018-0744-8
29. Domingos $\mathrm{CMH}$, lida LIS, Poveda VB. Glycemic control strategies and the occurrence of surgical site infection: a systematic review. Rev Esc Enferm USP. 2016;50(5):868-74. https://doi.org/10.1590/s0080-623420160000600022

30. Korol E, Johnston K, Waser N, Sifakis F, Jafri HS, Lo M, et al. A systematic review of risk factors associated with surgical site infections among surgical patients. PLoS ONE. 2013;8(12):e83743. https://doi.org/10.1371/journal. pone.0083743

31. [CDC] Centers for Disease Control and Prevention. Procedure-associated module: surgical site infection (SSI) event. Atlanta: CDC; 2016.

32. Ercole FF, Franco LMC, Macieira TGR, Wenceslau LCC, Resende HIN, Chianca TCM. Risk of surgical site infection in patients undergoing orthopedic surgery. Rev Latino-Am Enfermagem. 2011;19(6):1362-8. https://doi.org/10.1590/ s0104-11692011000600012 